\title{
E-læringsparadigmer og disses implikationer for valg og brug af e-læringsplatforme
}

\author{
Henrik Johannsen Duus \\ Lektor \\ Center of Market Economics \\ hjd.cme@cbs.dk \\ http://www.cme.cbs.dk
}

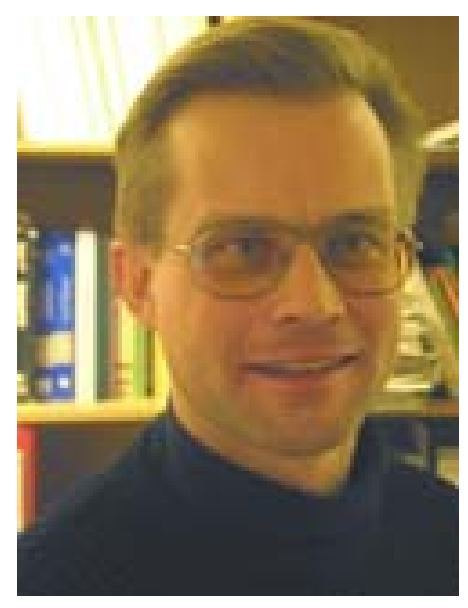

\section{Indledning}

E-læring er blevet et af tidens modeord. Med e-læring forstås almindeligvis læring ved hjælp af elektroniske midler, men denne definition er ganske bred og betyder vidt forskellige ting fra virksomhed til virksomhed og fra menneske til menneske. Den kan således omfatte alt fra off-line CDrom produkter til avanceret on-line virtuel læring i virtuelle læringsrum.

Mange af de hidtidige forsøg på at bringe orden i kaos gennem inddelinger og analyser er ikke tilfredsstillende. Hvis der ikke er tale om praksisfjern teori er der på det empiriske felt ofte tale om opremsninger af pædagogiske læringsstile (en unuanceret pædagogisk optik), teknologiske beskrivelser af forskellige læringssystemer (en unuanceret teknologisk optik) eller såkaldte branche- og markedsanalyser (en unuanceret konsulentoptik, som ved nøjere eftersyn (som regel) viser sig at være dårligt funderet i økonomisk teori og i marketing teori).

Ydermere er det et kæmpeproblem, at forskning og analyser retter sig mod "bredden" i e-læringsudbuddet. I stedet burde forskning og analyser gå i "dybden" med praktiske betragtninger af arbejdet på forfronten. Man burde gå fra "alt er lige godt” til "hvad gør de bedste bedre" betragtninger.

Jeg har valgt en anden måde at inddele e-læringsområdet, hvorefter e-læring bliver set som noget, der foregår på mange markeder (afhængigt af kunde/bruger behov), i to brancher (afhængigt af udbudsgrundlaget) og følgende fire paradigmer (afhængigt af verdensbilledet hos udbyderen). Disse paradigmers implikationer ved valg og udvikling af læringsplatform vil blive nærmere behandlet nedenfor. Den korte plads i denne artikel tillader mig ikke at gå i ret mange detaljer med andre aspekter end læringsplatforme, men en nærmere gennemgang af denne paradigmesynsvinkel kan findes i Duus (2003).

\section{E-læring i praksis}

Min synsvinkel er baseret på mit arbejde i et forskerfællesskab, som ikke bare har talt og skrevet om e-læring, men som selv har haft fingrene dybt nede i udviklings- og driftsarbejde (se f.eks. Undervisningsministeriet, 2000; Pettersson, 2002; Duus, 2003). Vores syn er her at e-læring ikke kan 
læres ved at læse publikationer, deltage i konferencer, kurser og workshops, eller ved at undersøge hvorledes andre har båret sig ad. For os er e-læring præget af tacit knowledge (Polanyi, 1966; Nonaka \& Takeuchi, 1995) dvs. erfaringsbaseret viden som man kun kan opnå ved at arbejde i tusindevis af timer ved computeren. Intet slår aktionsforskning, hvor man selv designer, udvikler og administrerer e-læringsforløb. E-læring minder herved som akademisk felt om kirurgi eller antropologi, idet den akademiske udvikling alle tre steder er kraftigt influeret af personlige praktiske erfaringer (Spender, 1994).

Denne aktionsforskningsorienterede tilgang har betydet, at vi har adskilt os voldsomt fra de fleste andre danske forskermiljøer indenfor e-læring, men til gengæld har det medført, at vi har kunnet udvikle, hvad vi har kaldt knowledge creation e-læring. Knowledge creation e-læring skal ses som noget andet end den mere almindelige knowledge transfer e-læring. Karakteristika ved begge dele er opsummeret i figuren nedenfor:

Figur 1: Skitsering af forskellen mellem knowledge creation e-læring og knowledge transfer e-læring (efter Duus (2002) og Duus (2003)).

\begin{tabular}{|c|c|c|}
\hline Karakteristika & Knowledge transfer e-læring & Knowledge creation e-læring \\
\hline Pædagogisk mål & $\begin{array}{l}\text { Formidling af viden og informationer via IKT-teknologi } \\
\text { som simpelt fremføringsmiddel. }\end{array}$ & $\begin{array}{l}\text { Skabelse af ny viden via kreativt brug af } \\
\text { IKT-teknologi. }\end{array}$ \\
\hline Økonomisk strategi & $\begin{array}{l}\text { Masseafsætning af lavkapitalintensiv produktion med } \\
\text { lav overskudsgrad. }\end{array}$ & $\begin{array}{l}\text { Eksklusiv afsætning af kapitalintensiv } \\
\text { produktion med høj overskudsgrad. }\end{array}$ \\
\hline Konkurrenceargument. & $\begin{array}{l}\text { Omkostningssænkninger i forhold til traditionel } \\
\text { uddannelse og instruktion. }\end{array}$ & $\begin{array}{l}\text { Differentiering af produktet. Virtual value } \\
\text { network development. }\end{array}$ \\
\hline Markedsføring & Aggressiv massemarkedsføring på "billighed". & Relationel markedsføring på "kvalitet". \\
\hline Praktiske karakteristika & $\begin{array}{l}\text { Off-line/on-line, synkron/asynkron, non-problem- } \\
\text { orienteret, lav-interaktiv. }\end{array}$ & $\begin{array}{l}\text { On-line, global 1-to-1 omnipræcens, } \\
\text { asynkronicitet, problem-orienteret, } \\
\text { dialogorienteret, TPP-princippet. }\end{array}$ \\
\hline $\begin{array}{l}\text { Ekstern fremtrædelses- } \\
\text { form }\end{array}$ & $\begin{array}{l}\text { Udlægning af dokumenter på net, off-line læringstek- } \\
\text { nologi, video, chat, simple dialogstrenge i netværk. }\end{array}$ & $\begin{array}{l}\text { Lukkede superfleksible intra- og extranets, } \\
\text { der kan understøtte alle former for } \\
\text { kommunikation - dog typisk ikke synkrone } \\
\text { former. }\end{array}$ \\
\hline Innovationsområder & $\begin{array}{l}\text { Primært teknologisk innovation, kun marginalt på non- } \\
\text { teknologiske områder. }\end{array}$ & $\begin{array}{l}\text { Omfattende innovation på faglige, } \\
\text { teknologiske, administrative, kulturelle, } \\
\text { pædagogiske, organisatoriske og alle andre } \\
\text { tænkelige områder. }\end{array}$ \\
\hline Virksomhedsdækning & Høj udbredelse. & Lav udbredelse. \\
\hline Anvendelsesområder & Kun uddannelse og træning. & $\begin{array}{l}\text { Alle former for læring - herunder forskning, } \\
\text { udvikling, uddannelse, træning, konsulent- } \\
\text { og projektarbejde. }\end{array}$ \\
\hline Rendyrkede eksempler. & $\begin{array}{l}\text { Findes i rigt mål blandt læringsteknologivirksomheder } \\
\text { og mange udbydere af e-uddannelser. } \\
\text { Opfattes fejlagtigt af mange som synonymt med e- } \\
\text { læring. Over } 95 \% \text { af al forsknings- og presseomtale af e- } \\
\text { læring har hidtil handlet om knowledge transfer e- } \\
\text { læring. }\end{array}$ & $\begin{array}{l}\text { Center of Market Economics (HD (A/U) og } \\
\text { A.P. Møller's e-mise uddannelse. } \\
\text { I mindre omfang Center for Innovation og } \\
\text { Entrepreneurship (kubuscompany \& } \\
\text { kubusnet) samt Forsikringshøjskolen. } \\
\text { Større danske virksomheders lukkede } \\
\text { netværk til forskning, udvikling og ledelses- } \\
\text { kommunikation. }\end{array}$ \\
\hline
\end{tabular}


At arbejde med et knowledge creation concept stiller store krav til fleksibillitet og dialogmuligheder, når vi taler om anvendelsen af læringsplatforme. Vores form for e-læring er bl.a. karakteriseret ved en ekstremt interaktiv problem- og deltagerstyret dialog (se mere på http://www.hd-au.cbs.dk). For at give et konkret indtryk, så er det hverdagskost med rent virtuelle fag med ca. 30 deltagere, hvor der er 30-40 indlæg om dagen igennem flere måneder, eller virtuelle seminarhold på 5-7 deltagere, hvor der er 60-70 indlæg om dagen i en periode på 3 uger.

Det faglige niveau er ganske højt og læringen er problemstyret. Der veksles mellem holdarbejde, gruppearbejde og individuelt arbejde, men alle får, som en selvfølge, en individuel behandling af virtuelle coaches, som arbejder i coaching-teams. Der udvikles i et sådant superinteraktivt virtuelt rum en særlig kultur, hvor alle kommer til at kende hinanden godt, og det er ganske almindeligt, at selv vores rent virtuelle studerende udtaler, at de ikke savner det sociale aspekt. Myten (skabt af pseudoeksperter) om at det er umuligt, at konstruere socialt velfungerende rent virtuelle uddannelser kan altså aflives.

I alt har vi konstant ca. 500 brugere, der fordeler sig med ca. $65 \%$ studerende på blended learning hold og ca. $15 \%$ studerende på rent virtuelle hold. Resten er teknisk-administrativt personale, internt og eksternt videnskabeligt personale samt ressourcepersoner fra erhvervslivet, som deltager i forsknings-, udviklings- og undervisningsprojekter. Vore studerende er i øvrigt alle erhvervsfolk, og specielt for de rent virtuelle studerende, er der som regel tale om rejser og udstationering. Vi har således studerende fra hele verden, som tager en videregående uddannelse i Danmark, mens de opholder sig arbejdsrelateret i udlandet. Fysisk ser vi dem som regel først til dimittendceremonien. At man arbejder på en fabrik i Amazon junglen, på en forskningsstation i Arktis eller i Tokyos stressede erhvervsliv er således ikke længere en hindring for at tage en videregående uddannelse i Danmark.

Vi har nydt godt af et samarbejde med A. P. Møller-Maersk gruppen, som har overtaget vores koncept $\mathrm{i}$ forbindelse med den såkaldte e-Mise uddannelse (se mere på http://www.mise.edu ). Flere andre virtuelle uddannelser er nu under udvikling, og igennem de sidste tre-fire år er vi desuden begyndt at bruge virtuel læring til forsknings- og udviklingsformål, bl.a. har vi skrevet en antologi ved hjælp af knowledge creation e-læring (http://www.knowledgecreation.dk). Derudover er der startet flere innovationsprojekter i danske virksomheder som en konsekvens af arbejdet i virtuelle læringsrum. Som det seneste er nogle virtuelle ph.d. uddannelsesforløb under opstart.

Alt dette stiller naturligvis store krav til vores læringssystem og vi har således som læringsplatform valgt en kombination af en dialogplatform (i form af sitescapesystemet som vi har brugt siden 1997, da det hed Alta Vista Forum, se http://www.sitescape.com) samt en Terminalserver med tynde klienter.

Terminalserveren er et uomgængeligt led i vores anvendelse af e-læring. Terminalserveren giver vore studerende over hele verden adgang til et omfattende datamateriale i form af elektroniske tidsskrifter, statistiske databaser og et meget varieret udbud af statistiske værktøjer. Denne adgang kan de studerende få uafhængigt af deres geografiske lokalisering, tidszone, deres personlige hardog software samt uafhængigt af deres personlige præferencer. Komplekse statistiske beregninger kan for eksempel udføres på terminalserveren, mens man sidder med sin egen lavtydende PC et tilfældigt sted i verden. Når terminalserveren er så vigtig skyldes dette ikke bare ønsrket om at give de studerende de bedst mulige teoretiske og praktiske værktøjer, men derimod det forhold, at problemstyret dialogbaseret læring i virtuelle læringsrum (som Sitescape) er totalt afhængigt af deltagernes opfattelse af substans og relevans. Med andre ord kan man ikke gennemføre superinteraktive problemstyrede virtuelle dialoger uden at den empiriske virkelighed bringes ind i det/de virtuelle 
rum. Herudover er enkelte yderligere komponenter vigtige for opnåelsen af den høje interaktivitet, bl.a. de personlige kompetencer hos de virtuelle coaches og deltagernes oplevelse af fortrolighed og sikkerhed i dialogerne. Den trange plads i denne artikel tillader mig ikke at gå i detaljer, men jeg vil her henvise til Pettersson (2002).

Som kraftigt antydet i det foregående er vores måde at arbejde med e-læring ganske atypisk, og en del af baggrunden kan findes i vores designpraksis, som har sammenhæng med hvorledes læringsplatformene bruges. Meget ofte ser man således at virksomheder, som udvikler en elæringsplatform laver teknologien først, og derefter overlader det til brugerne at indrette sig efter de begrænsninger i pædagogik og faglighed, der skabes af teknologien. Skrækeksemplet er kamerabaseret undervisning, som blot er en mere eller (som oftest) mindre perfekt gengivelse af gammeldags katederforelæsningspædagogik. Kun personer som intet ved om virtuel pædagogik kan finde på at foreslå eller anvende den slags.

Men det er ikke bare teknologien, som kan sætte begrænsninger for hvorledes e-læring kan udvikles og bruges. Pædagogikken og fagligheden kan også opstille begrænsninger som det vil fremgå af det efterfølgende, hvor jeg kort vil gennemgå fire forskellige måder at anvende læringsplatforme på.

\section{Paradigmer og læringsplatforme}

Som nævnt i indledningen har jeg opdelt e-læringsområdet i fire paradigmer. Disse er kortfattet beskrevet:

- Det markedsbaserede paradigme: Fokus på læring i et erhvervs/markedsperspektiv.

- Det pædagogiske paradigme: Fokus på læring i et traditionelt offentlig læreanstaltsperspektiv.

- Det teknologiske paradigme: Fokus på undervisning i et erhvervsperspektiv.

- Det fagbaserede paradigme: Fokus på undervisning i et traditionelt offentligt læreanstaltsperspektiv.

Denne opdeling er bl.a. en konsekvens af at skelne mellem læring og undervisning (se f.eks. Illeris, 2002), samt mellem erhvervsrettet tværgående forskning/udvikling og traditionel læreanstalts forskning (se f.eks. Duus, 2000).

Der er naturligvis tale om idealtyper (a la Max Weber), som ikke nødvendigvis behøver at korrespondere særligt godt til virkeligheden, men i praksis er disse fire paradigmer let genkendelige. Det markedsbaserede paradigme finder man repræsenteret ved en række mindre forsknings- og kursuscentre (bl.a. min egen organisation). Det pædagogiske paradigme finder man ofte hos forskere og udviklere indenfor pædagogik, kommunikation og organisation. Det teknologiske paradigme finder man hos de mange forskellige e-læring og læringsteknologi virksomheder, som er skudt op i det private erhvervsliv. Det fagbaserede paradigme er den måde e-læring som oftest anvendes på forskellige læreanstalter, hvor man blot søger at sætte strøm til undervisningen. 
Disse fire paradigmer har hver sin designpraksis, hvilket fremgår af nedenstående figur:

Figur 2. De fire paradigmers designpraksis (efter Duus (2003)).

\begin{tabular}{|c|c|c|c|}
\hline $\begin{array}{l}\text { Det Teknologiske Para- } \\
\text { digme }\end{array}$ & $\begin{array}{l}\text { Det Fagbaserede Para- } \\
\text { digme }\end{array}$ & $\begin{array}{l}\text { Det Pædagogiske Para- } \\
\text { digme }\end{array}$ & $\begin{array}{l}\text { Det Markedsbaserede } \\
\text { Paradigme. }\end{array}$ \\
\hline $\begin{array}{l}\text { Fase1: Leverancesystem- } \\
\text { design: } \\
\text { Leverancesystemet (pri- } \\
\text { mært teknologien) desig- } \\
\text { nes }\end{array}$ & $\begin{array}{l}\text { Fase 1: Faglige krav fast- } \\
\text { lægges: } \\
\text { Faglige krav fastlægges } \\
\text { udfra etablerede og tradi- } \\
\text { tionelle fagnormer }\end{array}$ & $\begin{array}{l}\text { Fase 1: Pædagogikken } \\
\text { fastlægges: } \\
\text { Pædagogikken fastlægges } \\
\text { udfra ideer i pædagogik- } \\
\text { forskningen }\end{array}$ & $\begin{array}{l}\text { Fase 1: Problemfastlæg- } \\
\text { gelse: } \\
\text { De reale problemer i } \\
\text { erhvervsvirksomhederne } \\
\text { fastlægges }\end{array}$ \\
\hline $\begin{array}{l}\text { Fase 2: Fagindhold ind- } \\
\text { sættes: Det som skal læres } \\
\text { tilpasses til leverance- } \\
\text { systemets muligheder for } \\
\text { at overføre viden }\end{array}$ & $\begin{array}{l}\text { Fase 2: Leverancesystem } \\
\text { vælges: } \\
\text { Det teknologiske leveran- } \\
\text { cesystem vælges ud fra det } \\
\text { som skal læres (ifølge } \\
\text { fagkravene) }\end{array}$ & $\begin{array}{l}\text { Fase 2: Fagindhold ind- } \\
\text { sættes: Det som skal læres } \\
\text { tilpasses til pædagogikken }\end{array}$ & $\begin{array}{l}\text { Fase 2: Fagindhold modi- } \\
\text { ficeres: } \\
\text { Det faglige indhold (det } \\
\text { som skal læres) redesignes } \\
\text { i lyset af erhvervslivets } \\
\text { behov }\end{array}$ \\
\hline $\begin{array}{l}\text { Fase 3: Pædagogikken } \\
\text { opbygges: Pædagogikken } \\
\text { designes ud fra de krav } \\
\text { som stilles af fagindhold } \\
\text { og leverancesystem }\end{array}$ & $\begin{array}{l}\text { Fase 3: Pædagogikken } \\
\text { opbygges: Pædagogikken } \\
\text { designes ud fra de krav } \\
\text { som stilles af fagindhold } \\
\text { og leverancesystem }\end{array}$ & $\begin{array}{l}\text { Fase 3: Leverancesystem } \\
\text { design: } \\
\text { Leverancesystemet (her- } \\
\text { under teknologien) desig- } \\
\text { nes/vælges ud fra den } \\
\text { ønskede pædagogik og } \\
\text { faglighed }\end{array}$ & $\begin{array}{l}\text { Fase 3: Pædagogik modi- } \\
\text { fikation: Pædagogikken } \\
\text { modificeres i lyset af det } \\
\text { som skal læres (dvs. det } \\
\text { faglige indhold) } \\
\text { Fase 4: Leverancesystem } \\
\text { design: } \\
\text { Leverancesystemet (her- } \\
\text { under teknologien) desig- } \\
\text { nes/vælges ud fra den } \\
\text { ønskede pædagogik og } \\
\text { faglighed }\end{array}$ \\
\hline
\end{tabular}

Som set i figur 2 er det markedsbaserede paradigme (som jeg tilhører) karakteriseret ved en prioritering af bruger/kundebehov. Ud fra disse fastlægges fagindhold og derefter pædagogik. Først til allersidst vælges leverancesystemet, som i sagens natur skal være så fleksibelt som overhovedet muligt. Dette er en betingelse som vores terminalserver og Sitescape dialogforum til fulde opfylder. Det skal understreges, at denne tilgang naturligvis ikke betyder at pædagogik, teknologi og faglighed nedprioriteres, snarere tværtimod. Det essentielle er blot at faglighed, teknologi og pædagogik bliver parametre, som underordnes bruger/kunde behov.

\section{Afslutning}

Man kan naturligvis ikke sige ret meget om hvilket paradigme, som er det bedste, idet dette fuldt ud afhænger af de målsætninger man har. Der er fordele og ulemper ved alle. Valget af paradigme må afhænge af om man ønsker at skabe god læring eller bare god undervisning, og om man ønsker at følge en traditionel forsknings- og udviklingsopfattelse eller om man ønsker at lave tværfaglig forskning og udvikling sammen med erhvervslivet. Valg og anvendelse af læringsplatforme vil være forskelligt fra paradigme til paradigme. For dem, der ønsker flere oplysninger kan jeg især henvise til Pettersson (2002) og Duus (2003) samt til de hyperlinks, som forekommer i denne artikel. 


\section{Litteratur}

Duus, Henrik Johannsen. "Den Nye Alliance i Videnssamfundet". Civiløkonomen, 1. (2000): 40-42.

Duus, Henrik Johannsen. E-learning Paradigmer og E-learning Strategiudvikling. Working paper. Copenhagen: Center of Market Economics, Copenhagen Business School, 2003.

Illeris, Knud. The Three Dimensions of Learning - Contemporary Learning Theory in The Tension Field between the Cognitive, The Emotional and The Social. Roskilde: Roskilde University Press, 2002.

Nonaka, Ikujiro \& Hirotaka Takeuchi. The Knowledge Creating Company. Oxford: Oxford University Press, 1995.

Pettersson, Michael. From E-learning to Knowledge Creation - Bridging the Gap between Learning and Working. Copenhagen: Center of Market Economics, Copenhagen Business School, 2002.

Polanyi, M. The Tacit Dimension. London: Routledge \& Kegan Paul, 1966.

Spender. J. C. "Workplace Knowledge as a Competitive Advantage - Management Education's Missed Targets”. In: Does Management Matter. Ed. Allan T. Malm, Crafoord Lectures nr. 6. Lund: Institute for Economic Research, 1994.

Undervisningsministeriet. Uddannelsesredegørelse 2000. København, Undervisningsministeriet. (se http://pub.uvm.dk/2000/ur/6.htm fra "Faglighed og nye udbudsformer"), 2000. 